\title{
Polityka energetyczna Unii Europejskiej w kontekście problematyki bezpieczeństwa gospodarczego
}

\begin{abstract}
Streszczenie: Artykuł stanowi analizę polityki energetycznej w kontekście bezpieczeństwa gospodarczego Unii Europejskiej. Jednym z kluczowych wyzwań, przed jakimi stoi UE, jest zapewnienie bezpieczeństwa gospodarczego zarówno jej członkom, jak również całej organizacji. Sektor energetyczny i polityka energetyczna stanowią integralny element strategii rozwoju Unii Europejskiej. Mogą one zarówno przyczyniać się do poprawy efektywności procesów integracyjnych, jak również stanowić przesłankę niepowodzenia projektu europejskiego. Celem artykułu jest dyskursywne zaprezentowanie wyzwań oraz problemów, jakie wiążą się z kształtowaniem europejskiej polityki energetycznej. Jej odpowiednie planowanie, zarządzanie oraz efektywne wdrażanie projektowanych $\mathrm{w}$ jej ramach mechanizmów stanowią conditio sine qua non sukcesu projektu integracyjnego. Brak skutecznych działań w tym zakresie grozi UE wzmocnieniem partykularyzmów narodowych, spowolnieniem gospodarczym, a w dalszej konsekwencji może powodować powolną erozję europejskiego systemu politycznego.
\end{abstract}

Słowa kluczowe: polityka energetyczna, sektor energetyczny, bezpieczeństwo gospodarcze, Unia Europejska, integracja europejska

ednym z kluczowych wyzwań, przed jakimi znajduje się współcześnie Unia Europejska, jest zapewnienie bezpieczeństwa gospodarczego zarówno jej członkom, jak również całej organizacji. Samo pojęcie bezpieczeństwa gospodarczego bywa różnie charakteryzowane w literaturze przedmiotu.

Najogólniej bezpieczeństwo gospodarcze można określić jako stan, w którym nie ma zagrożeń. Jednocześnie bywa ono definiowane - w sposób pozytywny - jako całokształt czynników i uwarunkowań zabezpieczających niezależność gospodarki narodowej, stabilność oraz zrównoważenie, gwarantujących jej doskonalenie się i systematyczny rozwój ${ }^{1}$ (Żukrowska, 2014, s. 99-105).

Na potrzeby niniejszego artykułu wykorzystana zostanie pozytywna definicja bezpieczeństwa gospodarczego, ponieważ ma ona charakter teleologiczny. Wyznacza cel, do którego ma zmierzać państwo, lub grupa państw. Definicja ta pozwala również analizować zagadnienia z uwzględnieniem dynamiki procesów politycznych, ekonomicznych i społecznych składających się na bezpieczeństwo gospodarcze.

Celem jest skoncentrowanie się przede wszystkim na zagadnieniach energii w Unii Europejskiej. Problematyka ta nabiera szczególnego znaczenia w kontekście kryzysu gospodarczego i politycznego, jakiego Stary Kontynent doświadcza w ostatnich latach

${ }^{1}$ Inne definicje akcentują np. wymiar politologiczny wskazując, iż bezpieczeństwo ekonomiczne jest to zdolność systemu gospodarczego państwa (lub grupy państw) do takiego wykorzystania wewnętrznych czynników rozwoju i międzynarodowej współzależności ekonomicznej, które będą gwarantowały jego (lub ich, tj. grupy państw) niezagrożony rozwój. 
(Wierzchowska, 2016, s. 395-396). Uzasadniając wybór tematu należałoby wskazać następujące problemy:

- prognozy gospodarcze wskazują na wzrost konsumpcji energii w UE w perspektywie do 2030 roku i dalszej;

- UE jest w znacznym stopniu uzależniona od zewnętrznych dostawców surowców energetycznych (zwłaszcza paliw kopalnych);

- ceny surowców kopalnych wykazują dużą zmienność w czasie i są silnie skorelowane z wahaniami międzynarodowej koniunktury gospodarczej (Wirl, 2008, s. 1029-1030);

- USD (dolar amerykański) pełni rolę waluty rozliczeniowej w transakcjach zakupu kluczowych surowców energetycznych, co dodatkowo utrudnia sytuację odbiorców w strefie euro.

Mając na uwadze powyższe, przedmiotem niniejszego artykułu jest analiza znaczenia sektora energetycznego i polityki energetycznej dla gospodarki europejskiej w perspektywie średnio- i długookresowej. W kontekście metodologicznym można postawić następującą hipotezę: przyszłość Unii Europejskiej jest uzależniona od poczucia bezpieczeństwa gospodarczego jej członków. Polityka energetyczna i sektor energii stanowią podstawę efektywnego funkcjonowania gospodarki europejskiej. Bez wdrożenia odpowiednich działań na rzecz bezpieczeństwa energetycznego (podejmowanych na poziomie wspólnotowym), UE grozi: wzmocnienie partykularyzmów narodowych, spowolnienie gospodarcze, a w dalszej konsekwencji powolna erozja europejskiego systemu politycznego.

Metodologia niniejszego artykułu obejmuje (na poziomie ogólnym) teorię realizmu międzynarodowego. Posłuży ona zobrazowaniu partykularnych interesów państw członkowskich w zakresie kształtowania sektora energetycznego. Na poziomie metody badawczej wykorzystana zostanie metoda systemowa, która pozwala na analizowanie Unii Europejskiej, jako szczególnego systemu politycznego i gospodarczego, w którym przenikają się bodźce pochodzące $\mathrm{z}$ otoczenia zewnętrznego Unii Europejskiej z bodźcami pochodzącymi z wewnątrz, czyli państw narodowych (Hix, 2010).

\section{Diagnoza sytuacji energetycznej Unii Europejskiej - między solidarnością europejską a "nacjonalizmem energetycznym”}

Prognozy gospodarcze dla Unii Europejskiej wskazują, iż w perspektywie najbliższych 25-30 lat zapotrzebowanie na energię będzie systematycznie wzrastało. Nie zmienią tego, ani rozwój technologii nastawionych na oszczędzanie energii, ani również kampanie społeczne adresowane do obywateli państw wysoko rozwiniętych, uświadamiające, potrzebę ograniczania zużycia energii. Społeczeństwo Unii Europejskiej nastawione na konsumpcję i systematyczne podnoszenie stopy życiowej, jest w coraz większym stopniu uzależnione od dostępu do energii. Staje się ona nośnikiem postępu cywilizacyjnego, a dostęp do niej jest miarą rozwoju społecznego. Świat pozbawiony energii, jest światem stagnacji, a gospodarka, w której występują przerwy w dostawach energii jest skazana na porażkę (Safa, 2017, s. 287-289). Trudno wyobrazić sobie efektywnie działające przedsiębiorstwa, wydajny sektor transportu czy funkcjonowanie sektora usług w warunkach występujących zakłóceń w dostawach energii czy surowców energetycznych. Z tych 
właśnie względów bezpieczeństwo energetyczne jest jednym z podstawowych celów polityki gospodarczej państw narodowych. Stało się ono również ważnym obszarem działania dla Unii Europejskiej (Nowak, 2009, s. 15).

Z danych publikowanych przez Komisję Europejską wynika, że UE importuje 53\% swojej energii, przeznaczając na ten cel ok. 400 mld euro, co czyni ją największym importerem energii na świecie. Sześć państw członkowskich jest uzależnionych od jednego zewnętrznego dostawcy całego importowanego gazu, co oznacza, że są one poważnie narażone na szoki podażowe. Szacuje się również, że zwiększenie oszczędności energii o każdy 1\% prowadzi do zmniejszenia importu gazu o 2,6\% (Komisja Europejska, 2014a). Z diagnozy Komisji Europejskiej wynika, iż blisko 75\% zasobów mieszkaniowych w UE ma niewielką efektywność energetyczną. Dodatkowo, aż 94\% transportu opiera się na produktach ropopochodnych, które w $90 \%$ pochodzą z importu. Łącznie UE wydaje ponad 120 mld euro rocznie - bezpośrednio lub pośrednio - na dotacje na energię, które często nie są uzasadnione (Komisja Europejska, 2014b). W sektorze energii w UE do 2020 roku trzeba zainwestować znaczące kwoty, sięgające miliardów euro ${ }^{2}$ (Komisja Europejska, 2015).

Ceny hurtowe energii elektrycznej w krajach europejskich są średnio o $30 \%$ wyższe niż w USA. Hurtowe ceny gazu ziemnego ciągle są blisko dwukrotnie wyższe niż w USA ${ }^{3}$. Takie różnice w cenach (w porównaniu do jednej z najbardziej konkurencyjnych gospodarek świata) mają znaczący wpływ na sytuację i konkurencyjność unijnego przemysłu, w szczególności, jeśli wziąć pod uwagę energochłonne jego sektory.

Pewnym optymizmem, na tle powyższych wskaźników, napawa analiza sektora odnawialnych źródeł energii. Europejskie przedsiębiorstwa reprezentujące tę branżę osiągają wspólnie roczne obroty na poziomie 129 mld euro i zatrudniają ponad milion osób ${ }^{4}$. Jednocześnie należy dodać, iż przedsiębiorstwa UE posiadają $40 \%$ wszystkich patentów na technologie pozyskiwania energii ze źródeł odnawialnych ${ }^{5}$. Kluczowym wyzwaniem pozostaje utrzymanie wiodącej roli Europy w globalnych inwestycjach w odnawialne źródła energii.

Zaprezentowana diagnoza sektora energetycznego Unii Europejskiej pozwala wysnuć szereg zróżnicowanych, mniej lub bardziej optymistycznych wniosków. Z jednej strony mamy do czynienia $z$ istotnymi problemami w zakresie kondycji sektora energetycznego, co wynika z faktu, iż bazuje on wciąż na kopalnych źródłach energii. Z drugiej jednak strony - sytuacja nie jest jednak dramatyczna, ponieważ europejski sektor energetyczny ma bardzo duży potencjał rozwojowy, zwłaszcza w obszarze nowych technologii, związanych z odnawialnymi źródłami energii. Mogą one stanowić ważny czynnik budowania niezależności energetycznej państw UE w stosunku do państw dostawców surowców energetycznych i jednocześnie stanowić kluczowy krok na drodze

${ }^{2}$ Szacunki Komisji Europejskiej. Tymczasem Międzynarodowa Agencja Energetyczna (MAE) szacuje, że do 2025 r. niezbędne będą nakłady w wysokości 1,3 biliona euro w zakresie wytwarzania, transportu i dystrybucji energii.

${ }^{3}$ Szacunkowe dane Dyrekcji Generalnej ds. Energii w oparciu o sprawozdania dotyczące rynku opracowane przez Platts oraz dane MAE, 2015.

${ }^{4}$ Sprawozdanie Eur'Observeur, 2014.

${ }^{5}$ W porównaniu do $32 \%$ udziału UE w patentach w skali światowej (dane Komisji Europejskiej, 2014). 
odchodzenia od paliw kopalnych w gospodarkach krajów wysokorozwiniętych (Hansen, Percebois, 2015, s. 36-37).

\section{Dzialania UE w zakresie polityki energetycznej - wyzwania i rzeczywistość}

Unia Europejska podejmuje działania w zakresie europejskiej polityki energetycznej na mocy postanowień Traktatu o funkcjonowaniu UE (TFUE, tzw. traktat lizboński). Jest to podstawowa legitymacja prawna do kształtowania wspólnych działań zarówno w wymiarze strategicznym, jak również w wymiarze operacyjnym. W art. 194 TFUE (tytuł XXI: Energetyka) zapisano, iż w ramach ustanawiania lub funkcjonowania rynku wewnętrznego oraz z uwzględnieniem potrzeby zachowania i poprawy stanu środowiska, polityka Unii w dziedzinie energetyki ma na celu, w duchu solidarności między państwami członkowskimi:

- zapewnienie funkcjonowania rynku energii;

- zapewnienie bezpieczeństwa dostaw energii w Unii;

- wspieranie efektywności energetycznej i oszczędności energii, jak również rozwoju nowych i odnawialnych form energii;

- wspieranie wzajemnych połączeń między sieciami energii.

Należy dodać, iż UE dostrzega silne powiązanie między sektorem energetycznym a problemami ochrony środowiska naturalnego. Znajduje to odzwierciedlenie w traktacie (TFUE), gdzie kwestie środowiskowe uregulowano w tytule XX. Cele w zakresie ochrony środowiska stanowią nieodłączny element unijnej polityki energetycznej.

Można dostrzec to również w działaniach podejmowanych w wymiarze strategicznym. W opublikowanym w lutym 2015 roku komunikacie Komisji Europejskiej Strategia ramowa na rzecz stabilnej unii energetycznej opartej na przyszłościowej polityce w dziedzinie klimatu (Komisja Europejska, 2015), stwierdzono wprost, iż działania strategiczne unii energetycznej opierają się na pięciu wzajemnie się wzmacniających i ściśle powiązanych obszarach mających na celu doprowadzenie do większego bezpieczeństwa energetycznego, stabilności i konkurencyjności. Zaliczono do nich:

- bezpieczeństwo energetyczne, solidarność i zaufanie;

- zintegrowany europejski rynek energii;

- efektywność energetyczną przyczyniającą się do ograniczenia popytu;

- dekarbonizację gospodarki;

- badania naukowe, innowacje i konkurencyjność.

Realizacja tych założeń wymaga przede wszystkim efektywnych działań na rzecz tworzenia wewnętrznego rynku energii oraz bardziej efektywnego zużycia energii. Dlatego Komisja opracowała swoistą mapę drogową, precyzującą najważniejsze kierunki działań. Wymienia się wśród nich przede wszystkim pełne wdrożenie i ścisłe egzekwowanie obowiązujących przepisów w dziedzinie energii i w dziedzinach powiązanych. Podkreśla się znaczenie dywersyfikacji dostaw gazu ziemnego i zmniejszenia wrażliwości gospodarki europejskiej na potencjalne zagrożenia w tym obszarze. Komisja wskazuje również na potrzebę dostosowania umów międzyrządowych, aby były w pełni zgodne z prawodawstwem UE, a jednocześnie bardziej transparentne. 
W tym kontekście istotna rola przypada także infrastrukturze energetycznej, która jest wstępnym warunkiem utworzenia rynku energii, zintegrowania odnawialnych źródeł energii oraz zapewnienia bezpieczeństwa dostaw ${ }^{6}$.

Osiągnięcie celów unii energetycznej wymaga poważnej transformacji systemu energetycznego w Europie. Ważne jest przede wszystkim zapewnienie: solidarności energetycznej, wolnego przepływu energii, efektywności energetycznej oraz przyjęcie na trwałe zasad społeczeństwa niskoemisyjnego.

Przygotowana przez Komisję strategia ramowa została przyjęta przez Radę Europejską na posiedzeniu w marcu $2015 \mathrm{roku}^{7}$. Rada Europejska potwierdziła gotowość do budowania unii energetycznej obejmującej pięć priorytetowych obszarów określonych w dokumencie Komisji (Turowski, 2015, s. 11-12). W konkluzjach wyróżniła szczególnie istotne aspekty unii energetycznej ${ }^{8}$ (Rada Europejska, 2015a). Na kolejnym posiedzeniu, w grudniu 2015 r., Rada Europejska odniosła się ponownie do sprawy, wzywając m.in. do przyspieszenia prac nad prawodawstwem w zakresie unii energetycznej czy pełnego wdrożenia prawa w dziedzinie energii ze źródeł odnawialnych i efektywności energetycznej (Rada Europejska, 2015b).

Mając na uwadze ramy prawne (prawo pierwotne i wtórne UE) oraz instytucjonalne (ogół instytucji UE odpowiedzialnych za kształtowanie polityki gospodarczej), jak również kwestie strategiczne, należałoby sądzić, iż Unia Europejska ma wszelkie możliwości, aby w efektywny sposób realizować ambitne cele w zakresie sektora energetycznego. Jednak patrząc z perspektywy funkcjonalno-relacjonalnej można dostrzec poważne ryzyka dla założeń przyjmowanych przez UE. Można byłoby je podzielić na endogeniczne (wynikające ze złożonej struktury wewnętrznej organizacji) oraz egzogeniczne (wynikające z uczestniczenia UE w stosunkach międzynarodowych z państwami trzecimi oraz innymi organizacjami międzynarodowymi).

\section{Endogeniczne:}

- zróżnicowanie sektora energetycznego w poszczególnych państwach UE - struktura produkcji energii jest uwarunkowana wieloma względami historycznymi oraz praktycznymi, wynikającymi z przyjętych rozwiązań gospodarczych. Wśród państw członkowskich znajdują się te, których gospodarki w większym (np. Polska) lub mniejszym stopniu (np. Włochy) są w stanie zapewnić sobie bezpieczeństwo energetyczne. Są państwa, których gospodarki są silnie uzależnione od paliw kopalnych (większość członków UE), ale również takie, które coraz powszechniej wykorzystują

${ }^{6}$ Komisja będzie wspierać realizację dużych projektów infrastrukturalnych, zwłaszcza projektów będących przedmiotem wspólnego zainteresowania, w ramach dostępnych środków finansowych, np. instrumentu „Łącząc Europę, europejskich funduszy strukturalnych i inwestycyjnych oraz przyszłego Europejskiego Funduszu na rzecz Inwestycji Strategicznych, aby pozyskać niezbędne środki prywatne i publiczne.

${ }^{7}$ Konkluzje Rady Europejskiej z 19-20 marca 2015 r., http://www.consilium.europa.eu/pl/press/ press-releases/2015/03/20-conclusions-european-council, 9.07.2017.

${ }^{8}$ W szczególności: w tym m.in.: prace nad infrastrukturą w dziedzinie energii elektrycznej i gazu (także połączenia międzysystemowe), pełna implementacja i rygorystyczne przestrzeganie przepisów energetycznych, zapewnienie zgodności umów dotyczących kupowania gazu od dostawców zewnętrznych z prawem UE (zwiększenie ich przejrzystości) czy opracowanie strategii w zakresie technologii i innowacji klimatyczno-energetycznych. 
odnawialne źródła energii (np. Szwecja, Niemcy) czy pozyskują energię z atomu (np. Francja, Belgia). Takie zróżnicowanie powoduje, iż w sprawach polityki energetycznej trudno jest państwom mówić jednym głosem. Rozbieżności w podejściu do wizji sektora energetycznego są trudne do pogodzenia;

- odmienna wizja poszczególnych państw ws. ksztaltowania relacji z państwami dostawcami surowców energetycznych, w szczególności w odniesieniu do Federacji Rosyjskiej - można dostrzec tutaj prawidłowość następującą: im dane państwo bardziej uzależnione jest od dostaw gazu rosyjskiego, tym mniejsza skłonność do podejmowania na forum UE decyzji nieprzychylnych Rosji (np. kwestia sankcji gospodarczych, jakie UE nałożyła na Federację Rosyjską w związku z kryzysem na Ukrainie, w marcu 2015 roku ${ }^{9}$;

- kolizja celów środowiskowych oraz celów energetycznych - Unia Europejska dąży do osiagnięcia pozycji światowego lidera w dziedzinie ochrony środowiska. Wyznacza ambitne cele redukcji emisji $\mathrm{CO}_{2}$. Jednocześnie wprowadza dla państw członkowskich restrykcyjne wymogi mające na celu wzrost wykorzystania technologii OZE oraz efektywności energetycznej. Oznacza to wysokie koszty transformacji sektora i może skutkować pogorszeniem pozycji konkurencyjnej zarówno poszczególnych państw członkowskich (np. program „Energiewende” realizowany w Niemczech), jak i całej Unii Europejskiej;

- wystąpienie Wielkiej Brytanii ze struktur UE (tzw. Brexit) - będzie oznaczało silne perturbacje dla gospodarki europejskiej, w tym również dla sektora energetycznego. Odwrócenie się Brytyjczyków od UE może - potencjalnie - stanowić silny bodziec antyintegracyjny dla pozostałych społeczeństw w państwach członkowskich i skutkować renacjonalizacją polityki energetycznej, w myśl zasady: lepiej budować samodzielną strategię bezpieczeństwa energetycznego, niż liczyć na wątpliwą solidarność europejską w tym zakresie.

\section{Egzogeniczne:}

- potrzeba poszukiwania nowych dostawców surowców energetycznych i wypracowania wspólnego języka w stosunku do państw trzecich, dostawców surowców energetycznych - uzależnienie gospodarki europejskiej od paliw kopalnych oznacza jednocześnie silne uzależnienie od dostaw surowców. Tymczasem dostawy te pochodzą albo rejonów niestabilnych politycznie (np. Afryki, Bliskiego Wschodu), albo z Federacji Rosyjskiej, która traktuje surowce w kategoriach narzędzi politycznego nacisku lub wykorzystywania ich do rozgrywania swoich interesów na forum UE. Oprócz Norwegii, z którą współpraca energetyczna układa się bez zastrzeżeń, Unia Europejska musi poszukiwać nowych kierunków. Najbardziej obiecujące wydaje się nawiązanie współpracy w tym zakresie z USA;

- uzależnienie gospodarki europejskiej od wahań cen surowców energetycznych na świecie - UE jest gospodarką opartą o wykorzystanie paliw kopalnych, których zasobów nie posiada w stopniu wystarczającym dla pokrycia swojego bieżącego i perspektywicznego zapotrzebowania. Oznacza to, iż osiaganie celów ekonomicznych UE jest mocno uzależnione od światowej koniunktury na surowce energetyczne;

${ }^{9}$ Szerzej na temat sankcji UE wobec Rosji na stronach Rady: Unijne sankcje w odpowiedzi na kryzys na Ukrainie, http://www.consilium.europa.eu/pl/policies/sanctions/ukraine-crisis/, 9.07.2017. 
- dolar USD jako waluta rozliczeniowa w transakcjach za surowce energetyczne na świecie - dolar amerykański pozostaje walutą rozliczeniową w transakcjach zakupu-sprzedaży surowców energetycznych. Oznacza to, iż zakupy surowców dokonywane przez państwa członkowskie UE są silnie skorelowane z kondycją gospodarki USA i kursem dolara wobec euro. Jest to zjawisko wyjątkowo niekorzystne, ponieważ naraża gospodarkę UE na ryzyko zmian kursu walutowego;

- poszukiwanie kompromisu środowiskowego na forum międzynarodowym - Unia Europejska dąży do wprowadzenia wysokich standardów ochrony środowiska (Komisja Europejska, 2014c). Jednak jej oczekiwania daleko rozmijają się z wizją USA, Rosji, Chin, Brazylii oraz Indii, czyli państw odgrywających kluczową rolę w kontekście emisji zanieczyszczeń. Podczas, gdy UE dąży do zrównoważonego rozwoju, pozostałe wymienione kraje myślą o efektywnym rozwoju gospodarczym i niechętnie godzą się na wprowadzanie jakichkolwiek ograniczeń, które mogłyby zaburzać ich narodowe strategie ekonomiczne. Oznacza to, iż głos UE, choć ważny z ideologicznego punktu widzenia, może okazać się w istocie nieskuteczny, a w konsekwencji doprowadzi do zachwiania pozycji konkurencyjnej gospodarek europejskich, zorientowanych na ochronę środowiska.

Analiza powyższych uwarunkowań dowodzi, że kształtowanie polityki energetycznej jest stale konfrontowane z licznymi problemami natury zarówno zewnętrznej, jak i wewnętrznej. Ich całkowite wyeliminowanie wydaje się niemożliwe. W tej sytuacji głównym wyzwaniem staje się świadome zarządzanie ryzykiem oraz optymalizacja działań pod kątem realizacji interesów wspólnotowych (Frączek, Gross-Gołacka, Kaliski, 2014, s. 15-18).

\section{Wpływ sektora energetycznego na bezpieczeństwo gospodarcze Unii Europejskiej}

Bezpieczeństwo energetyczne jest nierozerwalnie powiązane $\mathrm{z}$ bezpieczeństwem gospodarczym nie tylko $\mathrm{w}$ wymiarze pojedynczego państwa, ale również $\mathrm{w}$ odniesieniu do organizacji międzynarodowej, jaką jest Unia Europejska. Dla UE, która stawia przed swoimi członkami ambitne cele gospodarcze, stabilne funkcjonowanie sektora energetycznego stanowi gwarancję rozwoju. Jak wskazuje K. Żukrowska, bezpieczeństwo ekonomiczne stanowi podstawę zrównoważonego rozwoju oraz pozwala budować dobrobyt obywateli. (Raczkowski, Żukrowska, Żuber, 2013, s. 58). Duże znaczenie kontekstu międzynarodowego bezpieczeństwa ekonomicznego podkreśla - w szczególności - K. Księżopolski, wskazując iż oznacza ono przede wszystkim niezakłócone funkcjonowanie gospodarek narodowych (Księżopolski, 2011, s. 24-26).

Wpływ sektora energetycznego na bezpieczeństwo gospodarcze można ująć zarówno w wymiarze negatywnym, jak również pozytywnym. W wymiarze negatywnym można byłoby wskazać, iż brak zagrożeń ze strony sektora energetycznego stanowiłby mocną podstawę w kierunku działania na rzecz bezpieczeństwa ekonomicznego. Jednak bardziej trafne wydaje się spojrzenie pozytywne, ponieważ oddaje ono złożoność i współzależność, jaka cechuje sektor energii oraz funkcjonowanie innych dziedzin gospodarki. Wskazuje również na zjawisko ekonomizacji bezpieczeństwa (Procaccia, 2014, s. 385-390). 
Sektor energetyczny należałoby uznać zatem za jeden z filarów budowania bezpieczeństwa w innych obszarach, np. finansowym, żywnościowym, ekologicznym. Jest to efektem rosnącego uzależnienia społeczeństwa od energii, co pokazują nie tylko dane historyczne, ale również prognozy na przyszłość. $Z$ analiz opublikowanych w 2014 roku przez Międzynarodową Agencji Energii (MAE), wynika, że globalny popyt na energię wzrośnie o 37\% do 2040 roku (International Energy Agency, 2014). Jeżeli chodzi o paliwa kopalne, MAE prognozuje, że do 2035 roku zależność UE od importu ropy naftowej wzrośnie z ok. 80 do ponad 90\%. Podobnie oczekuje się, że zależność od importu gazu wzrośnie z 60 do ponad $80 \%$.

Reasumując, bezpieczeństwo energetyczne trudno zredukować jedynie do wymiaru narodowego. Zadania, które dotychczas znajdowały się w gestii pojedynczych państw, $\mathrm{w}$ dobie integracji europejskiej, winny stanowić priorytety do wspólnej realizacji. Należałoby w tym miejscu zaakcentować przede wszystkim następujące cele:

- stała dostępność do nośników energii;

- stabilne dostawy energii dla odbiorców biznesowych oraz indywidualnych;

- zmniejszenie zależności energetycznej poprzez dywersyfikację dostaw tych surowców;

- odpowiedni poziom ochrony obiektów energetycznych przed atakami terrorystycznymi;

- zróżnicowany bilans energetyczny (tzw. energy mix, poprzez zwiększenie wykorzystania źródeł odnawialnych);

- racjonalna gospodarka energia;

- wdrożenie mechanizmów rynkowych i nowych technologii.

Większość, spośród wskazanych wyżej priorytetów jest przedmiotem europejskiej polityki energetycznej. Niemniej jednak wątpliwości może budzić jakość oraz tempo ich praktycznego wprowadzania w życie (Komisja Europejska, 2015b).

Sektor energii, choć w warstwie dyskursywnej jest objęty wspólnymi działaniami, to jednak w praktyce państwa członkowskie w wielu ważnych sferach podejmują samodzielne działania, czego przykładem są chociażby:

- sektor energetyki jądrowej (każde państwo samodzielnie decyduje o rozwijaniu tej branży);

- sektor gazowy (indywidualne zakupy gazu od państw dostawców, budowa połączeń gazowych z państwami trzecimi - np. Nord Stream I, łączący Niemcy oraz Federację Rosyjską oraz planowany Nord Stream II - o podobnym znaczeniu);

- sektor energii odnawialnej - państwa samodzielnie określają tempo oraz sposób dochodzenia do wskaźników wykorzystania OZE w narodowym bilansie energetycznym.

Mając na uwadze powyższe, nasuwa się wniosek, iż sprawa bezpieczeństwa energetycznego wymyka się niejako spod kategorii unijnych i zyskuje wymiar narodowy (Safa, 2013, s. 11-12). Czy można byłoby osiagnąć w tym zakresie większą synergię na poziomie ponadnarodowym? Wydaje się to możliwe pod warunkiem zastosowania podejścia zintegrowanego. Oznaczałoby to, iż państwa członkowskie przekazują dalsze kompetencje na rzecz instytucji ponadnarodowych oraz rezygnują z postrzegania sektora energetycznego w kategoriach suwerenności państwowej. Pozwoliłoby to na rzeczywiste realizowanie założeń strategicznych proponowanych przez Komisję Europejska, a jednocześnie ograniczyło działania indywidualne, które nie służą interesom zbiorowym 
(np. budowa gazociagu Nord Stream II). Taki kierunek polityki energetycznej, zwłaszcza wobec osłabienia procesu tempa integracji, jakie obserwowane jest $\mathrm{w}$ ostatnich latach, wydaje się mało prawdopodobne.

Kolejny wniosek odnosi się do polityki ochrony środowiska. Unia Europejska wyraźnie określa ambitne cele w zakresie poszanowania klimatu, jednak wobec rozbieżności na arenie międzynarodowej (wynikających głównie z różnych oczekiwań państw rozwiniętych oraz rozwijających się) staje się ona swoistą enklawą, w której cele polityki klimatycznej zaczynają dominować nad problemami rozwoju gospodarczego. Taka idealistyczna wizja może kolidować z wyzwaniami w zakresie rozwoju gospodarczego Unii Europejskiej. Kluczem do odpowiedzi na to pytanie jest sektor energetyczny, który powinien stawić czoła rosnącemu zapotrzebowaniu na energię. Jednocześnie znajduje się on na cenzurowanym z powodu konieczności redukcji emisji oraz ograniczania paliw kopalnych w bilansach energetycznych państw członkowskich ${ }^{10}$.

Ta ostatnia zwłaszcza kwestia znajduje bezpośrednie odzwierciedlenie w Zielonej Księdze Ramy polityki w zakresie klimatu i energii do roku 2030. Podstawowe zagadnienia, które w dokumencie poruszyła Komisja, dotyczą poziomu ustalania celów dla polityki, tzn. czy powinny one być ustanawiane na poziomie UE, krajowym czy sektorowym oraz czy powinny być prawnie wiążące? (Komisja Europejska, 2013).

\section{Scenariusze rozwoju sytuacji w perspektywie średnio- i długoterminowej}

Polityka energetyczna i jej znaczenie dla bezpieczeństwa gospodarczego wymaga z pewnością perspektywicznego spojrzenia. Kreując przyszłość należałoby uwzględnić czynniki polityczne, ekonomiczne, społeczno-demograficzne oraz technologiczne (Bonin, Safa, Laureau, 2014, s. 2-6). Na tej podstawie można sformułować trendy, czyli długofalowe prawidłowości, którym podlegać będzie energetyka Unii Europejskiej. W kompleksowej analizie przygotowanej przez ekspertów z firmy Deloitte (Deloitte, 2016) wskazano na kilka zasadniczych tendencji w rozwoju energetyki. Należą do nich w szczególności:

- redukcja emisji i ochrona środowiska naturalnego stanowia jeden z zasadniczych i od wielu lat niezmiennych celów działania Unii Europejskiej. Działania w tym zakresie, choć dyskusyjne z ekonomicznego punktu widzenia czynią z UE światowego lidera w dziedzinie przeciwdziałania zmianom klimatycznym i poszukiwania alternatywnych sposobów na produkcję energii (Księżopolski, 2015, s. 67-68);

- rozwój technologii odnawialnych źródeł energii (OZE) i możliwości technicznych wytwarzania energii. Optymalizacja technologii oraz spadek kosztów wytworzenia

${ }^{10}$ Zwolennicy odnawialnych źródeł energii oraz efektywności energetycznej widzą rozwiązanie tych dylematów poprzez szersze wykorzystanie OZE oraz większe poszanowanie energii. Nie należy jednak zapominać, iż wykorzystanie źródeł odnawialnych nie jest rozwiązaniem w pełni satysfakcjonującym ze względu na wciąż wysokie koszty technologii oraz uzależnienie od warunków pogodowych (siły wiatru, nasłonecznia itp.). Moc nominalna może być daleko rozbieżna w porównaniu z mocą rzeczywistą, jaką jest w stanie wygenerować dla gospodarki podsektor odnawialnych źródeł energii. 
energii w źródłach odnawialnych, skutkują zwiększeniem ich dostępności zarówno dla prosumentów, jak i inwestorów instytucjonalnych, co może przełożyć się na zwiększenie udziału energetyki odnawialnej w miksie energetycznym.

- wzrost roli decyzyjnej i świadomości społeczeństwa - czynnik społeczny zyskuje na znaczeniu w kontekście funkcjonowania sektora energii w Unii Europejskiej. Następuje systematyczny wzrost świadomości obywateli w zakresie środowiska, oddziaływania inwestycji oraz nowych technologii wytwarzania energii. Obejmuje on w szczególności rosnącą świadomość i partycypację społeczną, sprzeciw wobec nowych inwestycji infrastrukturalnych oraz dążenie do autonomii w zaspokajaniu potrzeb energetycznych dzięki rozwojowi źródeł prosumenckich ${ }^{11}$.

- wzmocnienie mechanizmów efektywności energetycznej - działanie na rzecz zmniejszenia zużycia energii na jednostkę PKB stanowi jeden z kluczowych celów polityki energetycznej UE. Ważne jest, aby spadająca energochłonność PKB była powiązana z jednoczesnym rozwijaniem technologii ograniczających pobór energii w produkcji przemysłowej. W konsekwencji, jak prognozuje Deloitte, dalsze ograniczanie zapotrzebowania na energię $w$ gospodarce będzie miało wpływ na zmianę modeli biznesowych energetyki konwencjonalnej związanych np. z zarządzaniem popytem $^{12}$;

- nowe modele biznesowe i rola tradycyjnych przedsiębiorstw energetycznych - pojawienie się nowych możliwości w wytwarzaniu i dystrybucji energii, wynikających z rozwoju energetyki rozproszonej oraz zmiany roli i znaczenia tradycyjnej energetyki wielkoskalowej, prowadzi do rozwoju konkurencji nie tylko w wytwarzaniu i obrocie, ale także w przesyle i dystrybucji energii (Deloitte, 2016). W związku z długofalowymi zmianami w sektorze energetycznym, będą pojawiały się nowe możliwości dla podmiotów działających na zliberalizowanym rynku energii ${ }^{13}$.

Perspektywa zmian zarysowana w analizie Deloitte jakkolwiek realistyczna, wymaga przyjęcia założenia, iż proces integracji europejskiej będzie kontynuowany: państwa członkowskie będą efektywnie współpracować i realizować wspólną strategię działania w sektorze energetycznym. Taki scenariusz wydaje się jednak nieoczywisty wobec problemów, z jakimi zmaga się w ostatnich kilku latach Unia Europejska. Przemiany, które dotkną sektor energetyczny w średnio- i długoterminowej perspektywie wpłyną z pewnością na całą gospodarkę europejską.

Można je traktować z jednej z strony jako szansę, aby Unia mogła zwiększyć swój potencjał oraz poprawić pozycję konkurencyjną w skali globalnej (Lanthier, 2012, s. 15-21). Z drugiej jednak strony, brak efektywnej współpracy w zakresie polityki

${ }^{11}$ Wraz ze spadkiem cen technologii będzie rosło znaczenie mikrogeneracji OZE. W dłuższej perspektywie stroną przegraną może okazać się wielkoskalowy przemysł energetyczny, który nie jest zainteresowany tym segmentem rynku. Skutkiem będzie dalsza decentralizacja wytwarzania energii oraz potencjalnie utrata części rynku przez energetykę konwencjonalną (Deloitte, 2016).

12 Trend rozwoju inwestycji proefektywnościowych, wzmocniony przez postępujące urynkowienie technologii związanych z efektywnością energetyczną, wsparcie regulacyjne oraz rosnące ceny energii elektrycznej będą stopniowo prowadzić do eliminacji wsparcia dla tego rodzaju inwestycj (Ibidem).

13 Tradycyjny model biznesowy przedsiębiorstw energetycznych, oparty na scentralizowanym systemie będzie stopniowo zastępowany nowymi formami biznesu, lepiej dostosowanymi do rynku. Nowe, interesujące obszary pojawią się w produkcji OZE, efektywności energetycznej, przesyle i dystrybucji energii (Ibidem). 
energetycznej może skutkować spowolnieniem gospodarczym, a docelowo powodować osłabienie jedności europejskiej.

\section{Podsumowanie}

Spiritus movens współdziałania państw Starego Kontynentu były i pozostają nadal kwestie gospodarcze. Od zakończenia II wojny światowej poszukiwano skutecznego panaceum na przezwyciężenie powojennego marazmu oraz odbudowanie jedności Europy. Historia procesu integracji choć pisana przez polityków, naznaczona jest przede wszystkim przez działania w sferze gospodarczej. Dzięki wysiłkom państw członkowskich udało się zainicjować budowanie wspólnego rynku, a potem doprowadzić do unii gospodarczej i walutowej. Kiedy te podstawowe cele zostały osiagnięte pojawiły się nowe wyzwania w postaci zapewnienia bezpieczeństwa gospodarczego państwom tworzącym ugrupowanie integracyjne.

W tle tych działań znajduje się sektor energetyczny i polityka energetyczna. Odnosząc się do hipotezy postawionej na początku niniejszego artykułu, wypada potwierdzić, iż bez efektywnej współpracy państw w dziedzinie energii nie jest możliwy dalszy rozwój procesu integracji europejskiej. Pod pojęciem efektywnej współpracy autor tekstu rozumie przede wszystkim praktyczne zastosowanie modelu multi-level governance do polityki energetycznej, czyli zapewnienie skutecznej koordynacji strategii i działań na poszczególnych poziomach decyzyjnych od: państw członkowskich, instytucji wspólnotowych poprzez podmioty gospodarcze (działające w sektorze energetycznym), a także poszczególne podmioty subnarodowe (regiony i gminy wyposażone we władze samorządowe).

Bezpieczeństwo energetyczne jest dla Unii celem, który choć wydaje się bliski, zawsze pozostanie daleki, ponieważ nie można sformułować wobec niego warunku wystarczalności.

Rozwój sektora energetycznego dowodzi, że nie tylko w przeszłości, ale również w przyszłości będzie on miał kapitalne znaczenie dla gospodarki Unii Europejskiej oraz poszczególnych państw członkowskich. Świat się zmienia, a sektor energetyczny jest dziedzina, gdzie każdego dnia małe zmiany przyczyniają się do globalnej rewolucji, która oznacza nowe sposoby wytwarzania energii, stopniowe zmniejszanie wykorzystania paliw kopalnych oraz rozwój technologiczny. Zwłaszcza ten ostatni element może być silnym pozytywnym bodźcem dla gospodarki europejskiej.

Eliminowanie zagrożeń w sektorze energetycznym oraz systematyczne inwestowanie w jego rozwój, to jednocześnie świadoma inwestycja w bezpieczeństwo gospodarcze Unii Europejskiej w bliższej i dalszej przyszłości.

\section{Bibliografia}

Bonin B., Safa H., Laureau A. (2014), MIXOPTIM: A tool for the evaluation and the optimization of the electricity mix in a territory, "The European Physical Journal Plus”, 09/2014, vol. 129, nr 9, ss. 1-15.

Czaputowicz J. (2008), Teorie stosunków międzynarodowych. Krytyka i systematyzacja, Wydawnictwo Naukowe PWN, Warszawa. 
Deloitte (2016), Polska energetyka na fali megatrendów, Forum Analiz Energetycznych, Warszawa.

Frączek P., Gross-Gołacka E., Kaliski M. (2014), Zarzqdzanie zmianq w polityce energetycznej, „Ekonomika i Organizacja Przedsiębiorstwa”, nr 3, ss. 15-25.

Hansen J.-P., Percebois J. (2015), Énergie - économie et politiques, Wyd. De Boeck Superieur, Paris.

Hix S. (2010), System polityczny Unii Europejskiej, Wydawnictwo Naukowe PWN, Warszawa.

International Energy Agency (2014), World Energy Outlook - 2014.

Komisja Europejska (2013), Zielona Księga: Ramy polityki w zakresie klimatu i energii do roku 2030, COM 2013 (169).

Komisja Europejska (2014a), Komunikat: Efektywność energetyczna i jej wkład w bezpieczeństwo energetyczne a ramy polityczne dotyczqce klimatu i energii do roku 2030, COM (2014) 520.

Komisja Europejska (2014b), Komunikat: Europejska strategia bezpieczeństwa energetycznego, COM (2014) 330.

Komisja Europejska (2014c), Komunikat: Ramy polityczne na okres 2020-2030 dotyczqce klimatu i energii, COM (2014) 15.

Komisja Europejska (2015a), Komunikat: Strategia ramowa na rzecz stabilnej unii energetycznej opartej na przyszłościowej polityce w dziedzinie klimatu, COM (2015) 80.

Komisja Europejska (2015b), Komunikat: Stan unii energetycznej w 2015 r., COM (2015) 572.

Księżopolski K. M. (2011), Bezpieczeństwo ekonomiczne, Wydawnictwo ELIPSA, Warszawa.

Księżopolski K. (2015), Polityka energetyczno-klimatyczna Polski w latach 2014-2015, wyd. Instytut Badań nad Bezpieczeństwem, Energetyką i Klimatem, Warszawa.

Lanthier P. (2012), Les transitions énergétiques du point de vue de la consommation, w: Les défis énergétiques du XXI siècle. Transition, concurrence et efficacité au prisme des sciences humaines, red. Y. Bouvier, Wyd. P.I.E-Peter Lang, Bruxelles.

Nowak B. (2009), Energy Policy of the European Union, Wydawnictwo WAiP, Warszawa.

Procaccia H. (2014), L'Énergie nucléaire, les énergies fissiles et renouvelables. Quelle transition éneregtique pou la France de demain? Historique, bilan et perspectives, Editions Connaissances et savoirs, Paris.

Rada Europejska (2015a), Konkluzje 19-20 marca 2015.

Rada Europejska, (2015b), Konkluzje 17-18 grudnia 2015.

Ruszkowski J. (2010), Ponadnarodowość w systemie politycznym Unii Europejskiej, Wydawnictwo Wolters Kluwer, Warszawa.

Safa H. (2013), Quelle transition énergétique?, EDP Sciences, Paris.

Safa H. (2017), The Impact of Energy on Global Economy, "International Journal of Energy Economics and Policy", vol. 7, $\mathrm{nr}$ 2, ss. 287-295.

Traktat o funkcjonowaniu Unii Europejskiej (TFUE), wersja skonsolidowana, Dz. Urz. UE C 326 z 26.10.2012.

Turowski P. (2015), Wpływ unii energetycznej na bezpieczeństwo Polski. Wybrane przykłady, „Bezpieczeństwo Narodowe” IV, ss. 11-24.

Wierzchowska A. (2016), Wpływ modernizacji i kryzysu na dynamike zmiany w Unii Europejskiej, Wydawnictwo ELIPSA, Warszawa.

Wirl F. (2008), Why Oil Prices Jump (or Fall), „Energy Policy”, nr 36(3), ss. 1029-1043.

Żukrowska K. (2013), Ekonomia jako sfera bezpieczeństwa państwa, w: Interdyscyplinarność nauk o bezpieczeństwie. Paradygmat, wiedza, demarkacja, red. K. Raczkowski, K. Żukrowska, M. Żuber, Wydawnictwo Difin, Warszawa.

Żukrowska K. (2014), Bezpieczeństwo ekonomiczne, w: Trzy wymiary wspótczesnego bezpieczeństwa, red. S. Sulowski, M. Brzeziński, Wydawnictwo ELIPSA, Warszawa. 


\title{
Energy policy of the European Union in the context of economic security issues
}

\begin{abstract}
Summary
The article is an analysis of energy policy in the context of the economic security of the European Union. One of the key challenges facing the EU is to ensure the economic security both of its members, as well as of the entire organization. The energy sector and energy policy are an integral part of the European Union's development strategy. They may contribute to improved effectiveness of the integration process or to the failure of the European project. The aim of this article is to examine the challenges and problems that are associated with the formation of European energy policy. For the integration project to succeed, it is imperative for this policy to be properly planned and managed. Failing to implement appropriate mechanisms and actions to ensure energy security (taken at Community level), poses threats of strengthened national particularities in the EU, economic slowdown and, consequently, a slow erosion of the European political system.
\end{abstract}

Key words: Energy policy, energy sector, economic security, European Union, European integration 
